\title{
TRACING SUSTAINABLE OF BUFFALO SLAUGHTERHOUSE BASED ON KNOWLEDGE MANAGEMENT
}

\author{
Dyah Maharani ${ }^{1}$, Maya Dewi ${ }^{{ }^{*}}$ \\ Faculty of Engineering, Sahid University, Jakarta \\ *maya@usahid.ac.id
}

\begin{abstract}
The sustainability social dimension attributes of the Ruminant Slaughterhouse management can still be felt in the Buffalo Slaughterhouse which is located in Prambatan Kidul Village, Kaliwungu District, Kudus Regency, Central Java Province. This is reinforced by the results of the DyahMaharani's study (2015) which states that, the index of social dimension sustainability is 54.49 or in the category of quite sustainable. One of the attributes of leverage human interaction is illustrated by the active role of the attitude of the community of buffalo slaughterhouse business users, which is a hereditary profession. Human interaction is the attitude of tolerance and togetherness of the perpetrators of service users which shows a long history related to the spread of Islam in Kudus in the 15th century (fifteen). The strategy of humanization for worship in concrete operational and technical aspects includes respecting cattle ruminants. Until now the Kudus community still adheres to the ban on Sunan Sayyid Ja'far Shodiq Azmatkhan not to cut cattle ruminants, and as an alternative is buffalo ruminants. One of the advantages of buffalo ruminants as in the study (Aziz-urRehman, 2017) concluded that, buffalo animals, including ruminants, had a low chance $(1 \%)$ of paratuberculosis before being slaughtered, so that the resulting buffalo meat would be in accordance with the criteria for Safe-HealthyWhole-Halal).
\end{abstract}

Keywords: Buffalo-Slaughterhouse, Human interaction, Knowledge Management

\section{INTRODUCTION}

Satai, soto, buffalo meat-based cuisine is one of the icons that continues to be preserved in the Holy City and Regency of Central Java Province. This is a long history related to the strategy of humanization of worship carried out during the preaching of Sunan Kudus Sayyid Ja'far Shadiq Azmatkhan who at the time saw the local people already embraced Hinduism and were very respectful of cattle. Since then the people of Kota and Kabupaten Kudus, Central Java Province who want to consume meat choose to slaughter buffalo instea Conference on Community Development (ICCD) is the first collaborative practices journal of community development. In compiling these review articles, students will be better able to acquire the knowledge and the skills necessary for both the completion of their postgraduate theses, and their future careers as researchers and educators.

The components of a large amount of waste, the weight of life that is relatively heavier than that of cattle ruminants will increase the profits for the management of buffalo slaughterhouses. The implementation of the humanization strategy of worship about looking at the buffalo in the present remains relevant for popularization (Mas'udi, 2014). Therefore, Business Service Users want to increase useful knowledge in their non-formal organizations by familiarizing the culture of communication between service users, providing opportunities for sharing knowledge, sharing how to manage their organization, Human Resources, identifying the knowledge they have, storing and sharing within the Team to build and enhance the creation of innovation, and create conditions for how people from different places start to learn (Koentjoroningrat, 1984). 


\section{THEORETICAL FRAMEWORK}

The long history of the spread of Islam in Java has historical roots which until now have not yet been completed to understand the authenticity of its emergence. The strategy of religious tendency towards the teachings of Islam in Kudus (Mas'udi, 2014).Found 4 (four) leverage attributes included in the social dimension, each of which has a Root Mean Square (RMS) value of: (1) learning organization 5.57; (2) past experience 5.69; (3) human interaction 5.64 and culture of agriculture (livestock) 5.60. One of the attributes of leverage human interaction is illustrated by the active role of the attitude of the community of buffalo slaughterhouse business users, which is a hereditary profession. Human interaction is the attitude of tolerance and togetherness of the perpetrators of service users which shows a long history related to the spread of Islam in Kudus in the 15th century (fifteen).

\section{METHOD}

The study was conducted in Buffalo Slaughterhouse, in Prambatan Kidul Village, Kaliwungu District, Kudus Regency, Central Java Province. Data analysis methods used are: a). Multi-dimensional Scaling (MDS) with the use of Rap-Buffalo Slaughterhouse software; b) leverage analysis; c) montecarlo analysis, and prospective analysis. Materials used were attribute of social dimension based on knowledge management.

\section{Data Analysis}

Data analysis methods used are:a).Multi-dimensional Scaling (MDS) with the use of RapBuffaloSeaughterhouse software; b).leverage analysis; c).montecarlo analysis, and prospective analysis. To assess the sustainability status of the social dimension of the Buffalo Slaughterhouse service business, the Rap-BuffaloSlaughterhouse method has been modified from the Rapfish program with MDS techniques, such as the Cattle-Slaughterhouse system (Dyah-Maharani, 2015). In the MDS attributes or measures to be measured can be mapped within the distance of Euclidian Distance with the following formula:

$$
d_{1,2}=\sqrt{\left(X_{1}-X_{2}\right)^{2}+\left(Y_{1}-Y_{2}\right)^{2}+\left(Z_{1}-Z_{2}\right)^{2}+\ldots}
$$

Information :

$\mathrm{d} 1,2=$ Euclidean distance

$\mathrm{X}, \mathrm{Y}, \mathrm{Z}=$ Attributes

$1,2=$ Observation

The euclidean distance between these two points $(\mathrm{d} 1,2)$ then in MDS is projected into twodimensional euclidean distance (D1,2) based on the regression formula in the following equation:

$\mathrm{D} 1,2=\mathrm{a}+\mathrm{b} \mathrm{D} 1,2+\mathrm{c}$

Information :

$\mathrm{a}=$ intercept

$\mathrm{b}=$ slope

$\mathrm{c}=$ error

In MDS, the same two points or objects are mapped in one point that is close together. The technique used is ALSCAL algorithm and is easily available in almost every statistical software (SPSS and SAS). Rap-BuffaloSlaughterhouse in principle makes iterating the regression process in such a way that it gets the smallest e value and tries to force the intercept in the equation to be equal to $0(\mathrm{a}=0)$. Iteration stops if stress is $<0.25$ (Choe, 2001). For attributes as much as $\mathrm{m}$, stress can be formulated in the following equation: 
stress $=\sqrt{\frac{1}{m} \sum_{k=1}^{m}\left(\frac{\sum_{i} \sum_{j}\left(D_{i j k}^{2}-d_{i j k}^{2}\right)^{2}}{\sum_{i} \sum_{j} d_{i j k}^{2}}\right)}$

The amount of stress value is shown in Table 1

Table 1. The value of stress

\begin{tabular}{lll}
\hline No & Stress Value & Conformity \\
\hline 1 & $>20.00 \%$ & Bad \\
2 & $>(10.00-20.00) \%$ & Enough \\
3 & $>(5.00-10.00) \%$ & Good \\
4 & $(2.50-5.00) \%$ & Very good \\
\hline
\end{tabular}

Source: Kavanagh and Pitcher (2004)

\section{Leverage Analysis}

Leverage analysis to determine the effect of stability if one of the attributes is omitted when ordinated. Leverage analysis results show the percent change in the root mean square of each attribute. Attributes that have the highest percentage are the most sensitive attributes to sustainability (Kavanagh and Pitcher 2004).

\section{Monte Carlo Analysis}

To evaluate the effect of error on estimating ordination values, Monte Carlo analysis is used, which is a statistical simulation method to evaluate the effects of random errors in the estimation process, and to evaluate the actual value.

\section{Prospective Analysis}

According to (Puspaningrat et al., 2018)the objective analysis takes the form of the distribution of attributes that lie in the four quadrant scheme, namely: (1) quadrant-I is the determinant quadrant which is the quadrant of driving variables. This quadrant contains attributes that have a strong influence and low inter-attribute dependencies; (2) quadrant-II is the connecting quadrant which is the quadrant of leverage variables. This quadrant contains attributes that have strong influence and strong interdependence between attributes; (3) quadrant-III is the quadrant of results which is the output variables. This quadrant contains attributes that have low influence and strong inter-attribute dependencies; (4) quadrant-IV is the bound quadrant which is the quadrant of the marginal variables. This quadrant contains attributes that have low influence and low interdependence between attributes.

\section{RESULT AND DISCUSSION}

\section{Sustainability Index of Social Dimensions}

The index value of the sustainability of the social dimension of the Buffalo Slaughterhouse is 54.50 , the value is in the range of 50-75. (quite sustainable category). Leverage attribute analysis can be seen in Table 2 .

Table 2. Results of Leverage Attribute Analysis

\begin{tabular}{ccc}
\hline No & Description of Leverage Attribute & $\begin{array}{c}\text { Root Mean Square (RMS) } \\
\text { Value }\end{array}$ \\
\hline 1 & Learning organization & 5.57 \\
2 & Past experience & 5.69 \\
3 & Empowerment of Buffalo Farmers & 4.76 \\
4 & Ability to work together & 4.35 \\
\hline
\end{tabular}




\begin{tabular}{lcl}
\hline 5 & Workforce absorption & 4.57 \\
6 & Accessibility of communication & 4.75 \\
7 & Human interaction & 5.64 \\
8 & Agriculture culture & 5.60 \\
\hline
\end{tabular}

Past experience Users of Buffalo Slaughterhouse Service (5.69) are attributes that have the highest RMS value, a key factor that needs to be raised. Human interaction (5.64); agricultural culture, including animal husbandry (5.60); and Learning organization (5.57) are leverage attributes that have social values that are thought to be influential, because these attributes are built from generation to generation by the Prior Generation of Service Users. One function and role of social value is as a social glue and prevent violent conflict (Sumardjo, 2010).

\section{Validation of Sustainability in Social Dimensions}

Validation of Rap-BuffaloSlaughterhouse simulation results shows that the explanatory power or coefficient of determination $\left(\mathrm{R}^{2}\right)$ has a high enough value of 0.96 , which means that the 8 (eight) attributes included have a considerable role in explaining the diversity of business management Buffalo Slaughterhouse services social dimension built. Likewise, the value of S stress is 0.21 or lower than 0.25 which means the accuracy of the configuration of the dots (goodness of fit) of the model built for the sustainability of the social dimension of Buffalo Slaughterhouse can represent a good model (Alder et al., 2003)

\section{Prospective Analysis}

Based on the results of the prospective analysis presented in Figure 1, it was found that the types of distribution of attributes included in the sustainability of the social dimension of buffalo Slaughterhouse management tend to collect in Quadrants I and III. The meaning is if the government as the dominant factor in carrying out the action plan through empowering the Community of buffalo Slaughterhouse Community Service Users Buffalo, which has been proven to have the ability to cooperate since its predecessor generation, and is able to absorb labor is strongly influenced by past experience because they have strong human interaction and a powerful learning organization.

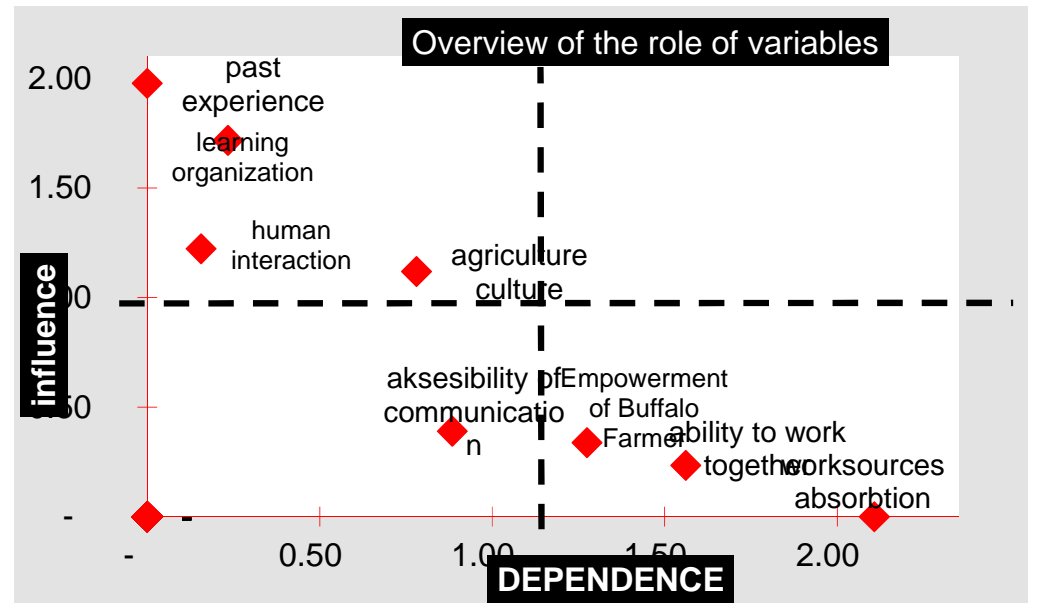

Figure 1. Attributes in the sustainability of buffalo Slaughterhouse management

\section{CONCLUSION}

The sustainability index of the social dimension of Buffalo Slaughterhouse, Prambatan Village, Kaliwungu District, Kudus Regency is quite sustainable (54.50). Found 4 (four) key factors were to be quite sustainable in the social dimension of the Buffalo Slaughterhouse namely: (1) past experience; (2) 
learning organization; (3) human interaction, and (4) agriculture culture. These four key factors are components in knowledge management.

\section{ACKNOWLEDGEMENT}

Author would like to thank to Buffalo-Slaughterhouse Prambatan Kidul, Kaliwungu, Kudus and also Mr. Ir. Sudibyo as the State Civil Apparatus Head of the Buffalo Slaughterhouse for his correction and suggestion on the manuscript, and Mrs. Witri Nugraheni, SH as staff from the Regional Apparatus for the Management of the Kudus Regency Regional Financial and Asset Revenues for her permission and willingness to accompany the author.

\section{REFERENCES}

Alder, J., Pitcher, T. J., Preikshot, D., Kaschner, K., \&Ferriss, B. (2000). How good is good?: A rapid appraisal technique for evaluation of the sustainability status of fisheries of the North Atlantic. Fish.Cent. Res. Rep., 8(2), 136-182.

Aziz-ur-Rehman. (2017). Prevalence and pathology of paratuberculosis in cattle and buffaloes at Faisalabad Abattoir. Pak. J. Agri. Sci., 54(1), 189-194. DOI: https://doi.org/10.21162/PAKJAS/17.5989

Choe, B. (2001). Nonmetric multidimensional scaling of complex sounds (Doctoral dissertation, Universität Oldenburg).

Maharani, M. D. D. Model Pengelolaan Usaha Jasa Rumah Potong Hewan Ruminansia Secara Berkelanjutan (Doctoral dissertation, Bogor Agricultural University (IPB)).

[FAO] Food Agricultural Organization. (1976). Recommended international code for hygienic practice for fresh meat. Rome: FAO/WHO

Kavanagh, P. (2001). Rapid Appraisal of Fisheries (RAPFISH) Project. RAPFISH Software Description (for Microsoft Excel). Vancouver: University of British Colombia. Fisheries Centre.

Koentjoroningrat. (1984). Budaya Jawa.Jakarta: Balai Pustaka

Puspaningrat, L.P.D., Pribadi, E. S., \& Dyah-Maharani, M. D. (2018). Identification of factors determining the business sustainability status of chicken collecting facilities and slaughterhouse in pondok rumput area, Bogor City. (Unpublished Thesis). Institut Pertanian Bogor, Bogor.

Mas'udi. (2014). Genealogi walisongo : Humanisasi strategi dakwah sunan kudus. Addin, 8(2), 223 244. DOI: http://dx.doi.org/10.21043/addin.v8i2.596

Sumardjo. (2010). Penyuluhan pembangunan menuju pengembangan capital manusia dan capital sosial, mewujudkan kesejahteraan rakyat, Orasi Guru Besar IPB (Unpublished), Institut Pertanian Bogor, Bogor. 